\title{
Silver Fir Decline in Mixed Old-Growth Forests in Slovenia: an Interaction of Air Pollution, Changing Forest Matrix and Climate
}

\author{
Jurij Diaci \\ Department of Forestry, Biotechnical faculty, University of Ljubljana
}

Slovenia

\section{Introduction}

Silver fir (Abies alba Mill.) is from ecological, economical and social point of view one of the most important conifer species in Europe (Kramer, 1992; Prpic et al., 2001). Many organisms are closely linked to silver fir dominated habitats. Silver fir (hereafter fir) can be very productive tree species in optimal site conditions. On siliceous, heavy soils in the lowlands it is more resistant to drought than Norway spruce (Picea abies (L.) Karst.). However, fir is extremely susceptible to environmental change (Schütt, 1978), including climate change (Brinar, 1964; Wick \& Möhl, 2006; Anic et al., 2009), wild ungulate browsing (Motta, 1996; Senn \& Suter, 2003), management regime (Mlinsek, 1964; Hockenjos, 2008) and air pollution (Eckstein et al., 1983; Krause et al. 1986; Elling et al., 2009). It is especially vulnerable to $\mathrm{SO}_{2}$ emissions. This was recognized by analyses of needles composition, comparative bioindication of sites with different emission loads and tree-ring studies (e.g. Wentzel, 1980; Elling, 1987; Elling et al., 2009). In Slovenia in 1980 the $\mathrm{SO}_{2}$ emissions amounted to about 235,795 tonnes/year and have significantly decreased until 2007 to 14,245 tonnes/year, which is almost 94\% (ARSO, 2010). The decrease of emissions in Slovenia started in late 1980s and influenced recovery of silver fir vitality and growth (Prelc et al., 1993; Ficko \& Boncina, 2006). Similar processes were reported also from other countries (Dobrowolska, 1998).

Beside air pollution also the climatic conditions, especially warm summers and repeated droughts had a significant impact on fir health (Mlinsek, 1964; Leibundgut, 1974; Becker et al., 1989; Bert, 1993; Thomas et al., 2002; Ficko et al., 2011). The first reports of local and regional fir decline in mixed fir-beech forests of the Dinaric Mountains date from the end of the 1920s (Safar, 1951). Sun exposed, rockier, and drier slopes were especially affected. The fir decline was probably triggered by harsh winters and hot, dry summers (e.g. 1950) and it was accompanied by bark beetle calamities.

Overbrowsing is another factor that can cause fir density decrease (Gill, 1992; Motta, 1996; Klopcic et al., 2010). Namely, fir combines several features that make it vulnerable to browsing: it is one of the most palatable species, it grows very slowly in shaded old-growth conditions, and it recovers poorly from browsing damage. Old-growth forests are often game reserves and are thus characterised by excessive game densities (Korpel, 1995; Kenderes et al., 2008; Vrska et al., 2009; Diaci et al., 2010). 
Again, other explanations of fir decline may include various ecological factors from complex pollutant interactions in forest soils (Ulrich, 1981), pathogen infections and changes in sapwood of unhealthy trees (Brill et al., 1981; Blaschke, 1982) to the impact of fir limited genetic variability in Central Europe, which may have caused lack of adaptability (Larsen, 1986). However, also direct influences of forest management on fir health seem important. They may include introduction of silvicultural systems not adapted to silver fir ecology (e.g. clear cut system), changing of forest climate by building of forest roads and racks as well as heavy fellings, favouring of other species (e.g. Becker et al., 1989; Kramer, 1992; Levanic, 1997; Hockenjos, 2008). Distinguishing between factors causing silver fir decline and mode of their operation (locally, regionally or globally) is important for several reasons. Firstly, understanding direct influences of environmental change may add to better environmental policies, for example overall forest die-back in Europe in 1980s led to significant reductions of $\mathrm{SO}_{2}$ emissions. Moreover, clear relations between management practices and response of tree species are important for silvicultural prescriptions and future forest management.

The vast majority of research on silver fir decline was carried out in managed forests, where natural factors (e.g. exceptional weather situations), indirect human influences (e.g. climate change, air pollution) were confounded with direct human influences (e.g. favouring of selected species by felling regime, silvicultural operations and building of forest road infrastructure). Therefore, research on mortality process in old-growth forest and forest reserves is extremely important to account for influence of management (Leibundgut, 1982; Korpel, 1995; Peterken, 1996). However, destructive methods, such as tree-ring analysis are often not allowed in protected forests, therefore long term studies of tree population structure are beneficial here. The oldest data from Slovenian old-growth forests dates back to 1892.

Mixed fir and beech (Fagus sylvatica L.) mountain forests represent one of the major forest types in Southeastern Europe (Horvat et al., 1974). They are well preserved since they have been influenced by humans to a lesser extent than lowland or high mountain forests have (Ficko et al., 2011). The majority of European temperate old-growth forests lie in this region (Leibundgut, 1982), while small-scale, uneven-aged silvicultural systems are typical of managed forests (Mlinsek, 1972).

Beside exogenous factors also endogenous factors as for example forest structure, tree architecture and tree age significantly affect the sensitivity of trees to emissions stress (Brinar, 1964; Bert, 1993; Ficko et al., 2011). Studies of forest decline in managed forests pointed out positive interactions between stand age and fir decline (Thomas et al., 2002). Dense stands, high competition and poorly developed and suppressed trees influence tree vulnerability to air pollution (Becker, 1989). On the other hand dominant trees with crowns above average might well receive higher concentrations of air pollutants - due to so called edge-effect (Filipiak \& Napierala-Filipiak, 2009). Therefore, different social statuses of trees (dominant, co-dominant and suppressed trees) seem important for the impact of air pollution and thus influence tree health condition.

The objectives of our study were to: (1) analyse temporal changes in fir density between four mixed old-growth forests in Slovenia, (2) analyse the relationship between tree social status and fir decline, (3) compare trends with managed forests and old-growth forests in neighbouring countries, and (3) discuss the relevance of natural and anthropogenic factors causing the decline and their spatiotemporal mode of operation. 


\section{Study site and methods}

Four mixed Dinaric old-growth forests from Slovenia were selected for this study: Strmec $\left(45^{\circ} 38^{\prime} \mathrm{N}, 14^{\circ} 49^{\prime} \mathrm{E}\right)$, Krokar $\left(45^{\circ} 33^{\prime} \mathrm{N}, 14^{\circ} 47^{\prime} \mathrm{E}\right)$, Rajhenavski Rog $\left(45^{\circ} 40^{\prime} \mathrm{N}, 15^{\circ} 01^{\prime} \mathrm{E}\right)$ and Pecka $\left(45^{\circ} 46^{\prime} \mathrm{N}, 15^{\circ} 00^{\prime} \mathrm{E}\right)$. All of the forests were located in the mountain vegetation belt of the Dinaric Mountains (Figure 1, Table 1). The bedrock consists of Cretaceous limestone for which karstic macro- and micro-topography is typical (e.g. sinkholes, rock outcrops). Due to variable microrelief different soil types could be found ranging from rendzic leptosols to calcocambisols. Soil depth was generally between 10 and $70 \mathrm{~cm}$. Forest sites in Pecka (hereafter PE) and Rajhenavski Rog (hereafter RR) were classified as the Dinaric fir-beech forest type (Omphalodo-Fagetum) according to the Braun-Blanquet typology (Puncer, 1980). In Strmec (hereafter ST) and Krokar (hereafter KR) $45 \%$ and $78 \%$ of forest sites were classified as Omphalodo-Fagetum, respectively. Other sites within ST and KR were classified as beech forests. In all old-growth forests the prevalent tree species was beech with the most recently recorded proportion in the growing stock ranging from $43 \%$ in RR to $93 \%$ in KR (Table 1). The second most important species was fir, whilst other species as sycamore maple (Acer pseudoplatanus L.), wych elm (Ulmus glabra Huds.), Norway spruce (Picea abies (L.) Karsten), common ash (Fraxinus excelsior L.) and large-leaved lime (Tilia platyphyllos Scop.) made up in general less than $1 \%$ of the total stem volume. All forests were protected by law as total reserves and no regular fellings were recorded. Forest disturbance regime was assumed to be driven by small canopy gap dynamics with occasional intermediate disturbances, especially in form of windthrow (Hartman, 1987; Nagel et al., 2006).

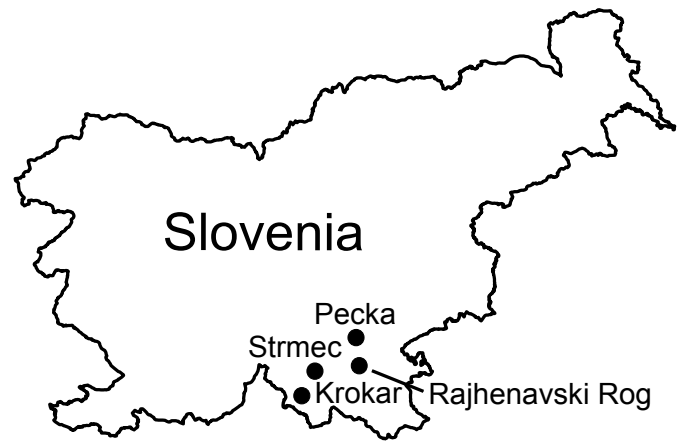

Fig. 1. Map of Slovenia with locations of four old-growth forest reserves. All reserves are located within Dinaric Mountains

Diameter distribution data was obtained from full callipering of the whole reserves in 10year intervals. In these inventories, the diameter at breast height (dbh) and species of each tree more than $10 \mathrm{~cm}$ in $\mathrm{dbh}$ in the entire reserve were recorded. Since the inventories from 1950s and 1960s for KR and PE didn't include the third dbh class $(10 \mathrm{~cm}<\mathrm{dbh} \leq 15 \mathrm{~cm})$, for calculation of indicators only trees thicker than $15 \mathrm{~cm}$ were taken into account, while the figures show all the original data. The oldest data for RR and PE (1892) came from the first forest management plan and it has been obtained through sampling transects (Boncina, 1999). The stem wood volume was calculated using the same volume tables for all years and old-growth forests (Cokl, 1992). For the purpose of studying the interaction between fir 
decline and tree social status three extended dbh classes were used (edbh1 $=15 \mathrm{~cm}<\mathrm{dbh} \leq$ $30 \mathrm{~cm}$, edbh2 $=30 \mathrm{~cm}<\mathrm{dbh} \leq 50 \mathrm{~cm}, \mathrm{edbh} 3=30 \mathrm{~cm}<\mathrm{dbh} \leq 50 \mathrm{~cm})$.

\begin{tabular}{|c|c|c|c|c|c|c|c|}
\hline Research site & $\begin{array}{c}\text { Stand } \\
\text { key }\end{array}$ & $\begin{array}{c}\text { Area } \\
\text { (ha) }\end{array}$ & $\begin{array}{c}\text { Altitude } \\
\text { a.s.l. }(\mathrm{m})\end{array}$ & $\begin{array}{c}\text { Average } \\
\text { annual } \\
\text { precipita- } \\
\text { tion }(\mathrm{mm})\end{array}$ & $\begin{array}{c}\text { Average } \\
\text { annual } \\
\text { tempera- } \\
\text { ture }\left(\mathrm{C}^{\circ}\right)\end{array}$ & $\begin{array}{c}\text { Parent } \\
\text { material }\end{array}$ & $\begin{array}{c}\text { Beech / } \\
\text { silver fir / } \\
\text { Norway } \\
\text { spruce } \\
\text { ratio }\end{array}$ \\
\hline Strmec & ST & 15.6 & $840-940$ & $\sim 1770$ & $6-7$ & Limestone & $79 / 21 / 0$ \\
Krokar & KR & 74.5 & $840-1170$ & $\sim 2000$ & 6 & Limestone & $93 / 7 / 0$ \\
Rajhenavski Rog & RR & 52.1 & $740-880$ & $\sim 1760$ & $6-7$ & Limestone & $43 / 57 / 0$ \\
Pecka & PE & 59.5 & $795-910$ & $\sim 1500$ & $6-7$ & Limestone & $82 / 18 / 0$ \\
\hline
\end{tabular}

Table 1. General characteristics of the four old-growth forests. Tree species ratio refers to the share in growing stock

\section{Results}

At the first inventory the highest fir share in the total tree density was recorded in RR (61\%) and the lowest in KR (29\%; Table 1). The same situation regarding ranking of fir share in the total tree density between the reserves was recorded also at the last inventory. However, during the same period fir share significantly decreased in all reserves. The highest absolute decrease in the fir share was recorded in PE, followed by KR, RR and ST. The time periods between the first and the last inventories were different between the reserves. Therefore, for a more objective comparison the annual difference in the fir share was calculated (Table 2). The highest annual decrease in fir share was recorded in ST, followed by KR, PE and RR.

\begin{tabular}{|c|c|c|c|c|c|}
\hline Old-growth forest & $\begin{array}{c}\text { Year of first / } \\
\text { last inventory }\end{array}$ & $\begin{array}{c}\text { Fir share in } \\
\text { density at } \\
\text { first } \\
\text { inventory }\end{array}$ & $\begin{array}{c}\text { Fir share in } \\
\text { density at last } \\
\text { inventory }\end{array}$ & $\begin{array}{c}\text { Difference in } \\
\text { fir share }\end{array}$ & $\begin{array}{c}\text { Difference in } \\
\text { fir share / } \\
\text { year }\end{array}$ \\
\hline Strmec & $1984 / 2004$ & $45.7 \%$ & $34.0 \%$ & $-11.7 \%$ & $-0.59 \%$ \\
Krokar & $1961 / 2004$ & $28.9 \%$ & $12.0 \%$ & $-16.9 \%$ & $-0.39 \%$ \\
Rajhenavski Rog & $1957 / 2007$ & $61.0 \%$ & $48.9 \%$ & $-12.1 \%$ & $-0.24 \%$ \\
Pecka & $1953 / 2003$ & $36.7 \%$ & $19.0 \%$ & $-17.7 \%$ & $-0.35 \%$ \\
\hline
\end{tabular}

Table 2. Changes of fir share in the total tree density

Fir density $(\mathrm{dbh}>15 \mathrm{~cm})$ at the first inventory spanned from 168.2 trees/ha in ST to 94.8 trees/ha in KR (Table 3). During following years it decreased in all reserves and reached highest values during the last inventory in RR with 97.3 trees/ha and lowest values in KR with 33.0 trees/ha. Maximum difference between the first and the last inventory divided by year (annual rate of fir density change; hereafter ARC) was recorded in ST, followed by PE, KR and RR with $-3.67,-2.16,-1.44$ and -1.28 trees/ha/year, respectively. However, it seemed likely that old-growth forests with higher fir initial density would have had experienced a higher absolute fir decrease. Therefore, ratio between initial and observed fir density was introduced as a more objective indicator of fir decline intensity. The highest relative annual rate of change (hereafter RARC) was recorded in ST, followed by KR, PE and RR. 


\begin{tabular}{|c|c|c|c|c|c|c|}
\hline $\begin{array}{c}\text { Old-growth } \\
\text { forest }\end{array}$ & $\begin{array}{c}\text { Fir density } \\
\text { at first } \\
\text { inventory } \\
\text { (a) }\end{array}$ & $\begin{array}{c}\text { Fir density } \\
\text { at last } \\
\text { inventory } \\
(\mathrm{b})\end{array}$ & $\begin{array}{c}\text { Difference } \\
\text { in fir } \\
\text { density } \\
(\mathrm{b}-\mathrm{a})\end{array}$ & $\begin{array}{c}\text { Annual } \\
\text { rate of fir } \\
\text { density } \\
\text { change } \\
(\text { ARC) } \\
(\text { (b- } \\
\text { a)/year })\end{array}$ & $\begin{array}{c}\text { Ratio } \\
\text { between } \\
\text { initial and } \\
\text { final fir } \\
\text { density } \\
(\mathrm{b} / \mathrm{a})\end{array}$ & $\begin{array}{c}\text { Relative } \\
\text { annual rate } \\
\text { of fir } \\
\text { density } \\
\text { change } \\
\text { (RARC) } \\
\text { (b/a/year) }\end{array}$ \\
\hline $\begin{array}{c}\text { Strmec } \\
\text { Krokar }\end{array}$ & 168.2 & 94.7 & -73.4 & -3.67 & $56.3 \%$ & $-2.18 \%$ \\
Rajhenavki Rog & 161.1 & 33.0 & -61.8 & -1.44 & $34.8 \%$ & $-1.52 \%$ \\
Pecka & 146.5 & 38.3 & -108.2 & -2.16 & $26.2 \%$ & $-1.48 \%$ \\
\hline
\end{tabular}

Table 3. Changes in fir density between the first and last inventory. All data are per ha

For the old-growth forests $\mathrm{RR}$ and $\mathrm{PE}$ data on the fir density from the first forest management plan was available (Table 4). These data may serve only as a rough estimate of conditions at that time, since forest compartments were larger, inventory was based on sample transects, and only the trees up to $80 \mathrm{~cm}$ in the $\mathrm{dbh}$ were measured. Comparison of the fir density among the first measurements in 1892 and inventories in the 1950s showed relatively small differences in both old-growth forests. RARC was in the case of RR positive and amounted to only $0.01 \%$, and it was negative in the case of PE and amounted to $-0.06 \%$.

\begin{tabular}{|c|c|c|c|c|c|c|}
\hline $\begin{array}{c}\text { Old-growth } \\
\text { forest }\end{array}$ & $\begin{array}{c}\text { Fir density } \\
\text { in 1892 (a) })\end{array}$ & $\begin{array}{c}\text { Fir density } \\
\text { in 1950s (b) }\end{array}$ & $\begin{array}{c}\text { Difference } \\
\text { in fir } \\
\text { density } \\
\text { (b-a) }\end{array}$ & $\begin{array}{c}\text { Annual } \\
\text { rate of fir } \\
\text { density } \\
\text { change } \\
(\text { ARC) } \\
(\text { (b- } \\
\text { a)/year })\end{array}$ & $\begin{array}{c}\text { Ratio } \\
\text { between } \\
\text { initial and } \\
\text { final fir } \\
\text { density } \\
\text { (b/a) }\end{array}$ & $\begin{array}{c}\text { Relative } \\
\text { annual rate } \\
\text { of fir } \\
\text { density } \\
\text { change } \\
\text { (RARC) } \\
\text { (b/a/year) }\end{array}$ \\
\hline $\begin{array}{c}\text { Rajhenavski Rog } \\
\text { Pecka }\end{array}$ & 160.0 & 161.1 & 1.1 & 0.02 & $100.7 \%$ & $0.01 \%$ \\
92.0 & 146.5 & -5.5 & -0.09 & $96.4 \%$ & $-0.06 \%$ \\
\hline
\end{tabular}

Table 4. Changes in fir density between the first inventory in 1892 for both old-growth forests and inventory in 1953 for PE and 1957 for RR. Density data for all inventories is for trees with $\mathrm{dbh}>15 \mathrm{~cm}$. During the first inventory only trees up to $\mathrm{dbh}<80 \mathrm{~cm}$ were measured

We calculated ARC and RARC for periods between individual inventories for all oldgrowth forests. On the Figure 2 the mean ARC and RARC values in different periods were plotted against mean year of the period. For example, in ST there were three inventories: 1984, 1994 and 2004. ARC for the first (1984-1994) and second (1994-2004) period were -1.92 and -5.42 trees/ha/year, respectively. The mean years of the first and second period used for plotting of ARC were 1989 and 1999, respectively. As with all parameters in Tables 2 and 3 all ARC and RARC values were negative. The highest ARC values were -5.42 trees/ha/year in ST between 1994-2004, and -2.86 trees/ha/year for PE between 1953-1973. While the lowest ARC values -0.29 trees/ha/year were recorded in RR between 1957-1967, and -0.44 in PE between 1994-2003. RARC values spanned in interval from -0.18\% (RR 19571967) and $-3.64 \%$ (ST 1994-2004). The development of RARC indicator showed a similar 
course for the three forest reserves, KR, RR and PE. At the first and last inventories the index values were higher, and in the interim the lowest values were achieved. All minima were reached during 1980s. However, ST with shorter interval of inventories showed a steep decline during the last period.
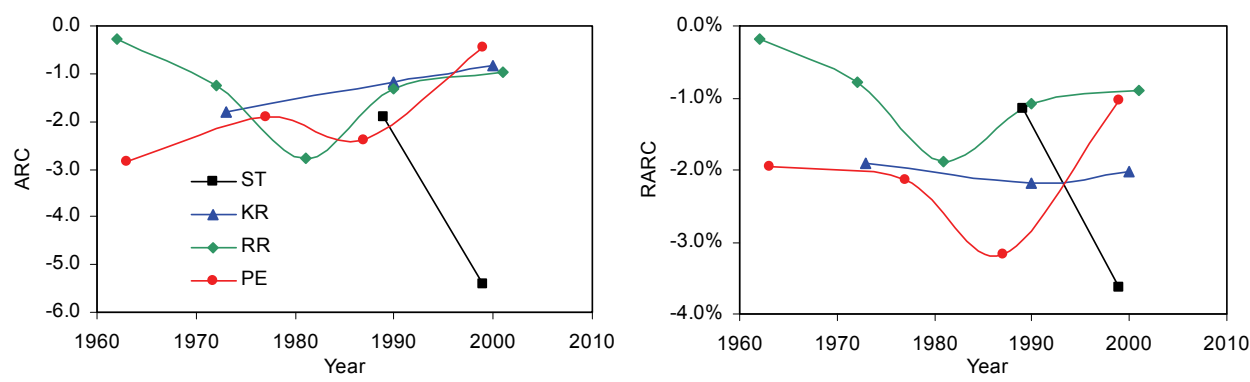

Fig. 2. Left: Annual rate of fir density change ARC (trees/ha/year) for four old-growth forests: $\mathrm{ST}=$ Strmec, $\mathrm{KR}=$ Krokar, RR = Rajhenavski Rog, PE = Pecka; Right: Relative annual rate of fir decline RARC (trees/ha/year/initial density of the period)

Further we were interested how fir decline affected trees with different social status (Table 5). As a surrogate for the tree social status, extended dbh classes were used (edbh). Tree diameter at breast height is namely closely related to tree height and social status. It was assumed that tress in edbh1 were mostly suppressed, tress in edbh2 were about to establish in the canopy layer, while trees in edbh3 formed the upper canopy layer and dominant individuals.

\begin{tabular}{|l|c|c|c|c|c|c|c|c|c|}
\hline & \multicolumn{3}{|c|}{ Strmec } & \multicolumn{7}{c|}{ Rajhenavski Rog } \\
\hline & $1984-$ & $1994-$ & $\mathbf{1 9 8 4 -}$ & $1957-$ & $1967-$ & $1976-$ & $1985-$ & $1995-$ & $\mathbf{1 9 5 7 -}$ \\
& 1994 & 2004 & $\mathbf{2 0 0 4}$ & 1967 & 1976 & 1985 & 1995 & 2007 & $\mathbf{2 0 0 7}$ \\
\hline edbh1 & $-0.58 \%$ & $-3.54 \%$ & $\mathbf{- 1 . 9 6 \%}$ & $-0.37 \%$ & $-1.02 \%$ & $-3.50 \%$ & $-0.94 \%$ & $-1.34 \%$ & $\mathbf{- 1 . 0 9 \%}$ \\
edbh2 & $-0.88 \%$ & $-3.71 \%$ & $\mathbf{- 2 . 1 3} \%$ & $-0.92 \%$ & $-1.38 \%$ & $-1.93 \%$ & $-2.03 \%$ & $-1.09 \%$ & $\mathbf{- 1 . 0 9 \%}$ \\
edbh3 & $-3.23 \%$ & $-3.91 \%$ & $\mathbf{- 2 . 9 4} \%$ & $0.48 \%$ & $-0.26 \%$ & $-0.71 \%$ & $-0.72 \%$ & $-0.58 \%$ & $\mathbf{- 0 . 3 4 \%}$ \\
\hline \multicolumn{8}{|c|}{ Krokar } & & \multicolumn{7}{c|}{ Pecka } \\
\hline & $1961-$ & $1984-$ & $1995-$ & $\mathbf{1 9 6 1 -}$ & $1953-$ & $1973-$ & $1980-$ & $1994-$ & $\mathbf{1 9 5 3 -}$ \\
& 1984 & 1995 & 2004 & $\mathbf{2 0 0 4}$ & 1973 & 1980 & 1994 & 2003 & $\mathbf{2 0 0 3}$ \\
\hline edbh1 & $-2.02 \%$ & $-1.35 \%$ & $-1.82 \%$ & $\mathbf{- 1 . 4 4} \%$ & $-2.33 \%$ & $-2.86 \%$ & $-1.59 \%$ & $0.99 \%$ & $\mathbf{- 1 . 2 8 \%}$ \\
edbh2 & $-2.22 \%$ & $-3.37 \%$ & $-1.31 \%$ & $\mathbf{- 1 . 6 9 \%}$ & $-2.86 \%$ & $-1.79 \%$ & $-3.38 \%$ & $-1.26 \%$ & $\mathbf{- 1 . 6 5 \%}$ \\
edbh3 & $-0.69 \%$ & $-2.48 \%$ & $-3.56 \%$ & $\mathbf{- 1 . 3 6} \%$ & $-1.06 \%$ & $-1.82 \%$ & $-3.94 \%$ & $-2.84 \%$ & $\mathbf{- 1 . 5 4 \%}$ \\
\hline
\end{tabular}

Table 5. Relative annual rate of fir density change RARC (trees/ha/year/initial density of the period) according to periods between inventories, extended dbh classes (edbh) and oldgrowth forests. Note: edbh1 $=15 \mathrm{~cm}<\mathrm{dbh} \leq 30 \mathrm{~cm}$; edbh2 $=30 \mathrm{~cm}<\mathrm{dbh} \leq 50 \mathrm{~cm}$; edbh $3=$ $30 \mathrm{~cm}<\mathrm{dbh} \leq 50 \mathrm{~cm}$

We hypothesized that the dominant trees were most vulnerable to air pollution, since they were most directly exposed to its negative impacts. This was the case in ST for two periods, 
in PE for two periods, and in KR for one period. However, trees in edbh2 exhibited higher RARC during six periods (tree periods in RR, two in KR and one in PE), while the highest RARC in the suppressed trees of edbh1 was found during three periods (two periods in RR and one in PE). From this analysis we could not confirm the hypothesis about the greater sensitivity of the dominant trees to air pollution. Moreover, the lowest RARC was most frequently recorded in the sub-canopy tree layer (edbh2). This result is even more obvious if we compare RARC over the whole inventory periods (Table 4); it was the lowest in edbh2 for three out of four old-growth forests.

Figure 3 shows changes in empirical dbh distributions for selected years of inventories. A strong reduction in the number of fir trees is obvious throughout all periods. However, comparisons of dbh distributions also suggest differences in the structure of the fir regression. In the case of KR a substantial reduction within small and medium diameter trees was recorded, while large diameter trees were already rare at the first inventory. In PE and ST the fir reduction was more balanced across the whole dbh range. A special case was $\mathrm{RR}$, where fir decrease was more pronounced within small and medium diameter tress, while large diameter trees have been shifted to even larger diameter classes.
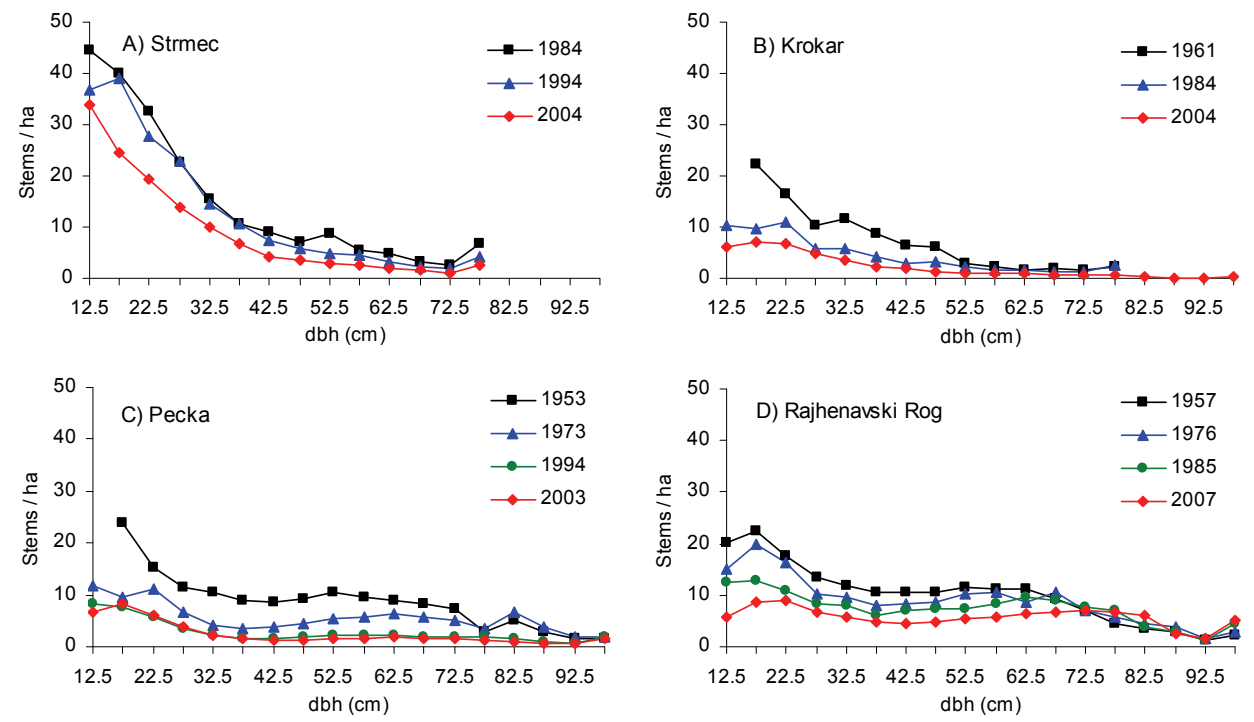

Fig. 3. Temporal changes of silver fir empirical diameter distributions for four mixed oldgrowth forests in Slovenian Dinaric Mountains

\section{Discussion}

First observations of fir decline in Slovenia were made in 1956 (Brinar, 1964; p. 111), they triggered research which focused on managed forests (Mlinsek, 1964). Fir decline in oldgrowth forests was underestimated, probably due to the abundance of old and non-vital trees, although old-growth forests may be more sensitive to air pollution than younger, managed forests. Because there was no awareness of fir decline in old-growth forests 
arguments emerged, that the fir decline in managed forests was triggered or influenced by heavy and unregulated post World War II. fellings. However, the first studies didn't confirm that hypothesis (Brinar, 1964). Our results also suggested a rather early start of the fir decline in old-growth forests. It is necessary to take into account the fact, that the studied old-growth forests were in the Dinaric part of Slovenia, which was not exposed to heavy direct emissions at the time. Therefore, long-range transport of pollutants might have been more important, while direct emissions became more intense later, especially during 1970s and 1980s. Thus, the results from our research don't support the primary hypothesis that forest management had a significant impact on silver fir decline in Slovenia. Similar results on early silver fir decline were reported also for mixed old-growth forests in other regions of Europe (e.g. Korpel, 1995; Diaci et al., 2008).

Our results indicate that the intensity of fir decline varied between the old-growth forests. The most significant decline was recorded in ST and KR. For both old-growth forests also some extreme, especially steeper slopes were characteristic, which were only partly overgrown by community Omphalodo-Fagetum. Both forests covered more pronounced mountain ridges compared to RR and PE, and their average altitude was slightly higher. ST was also characterized by dry sun exposed slopes. More intensive fir regression at the border of its natural distribution and on dryer sites was also reported by Ficko et al. (2011) for managed forests in Slovenia. Thomas et al. (2002) reported positive relationship between mean altitude and fir decline.

During last hundred years fir density in old-growth forests significantly changed. In the second half of the 19th century the extinction of large herbivores triggered abundant fir regeneration (Klopcic et al., 2010). Therefore, fir density gradually increased until the mid 20th century, when reintroduced ungulates reached excessive densities and overbrowsing begun. This was coupled with an increase of air pollution due to industrialisation. Our oldest data on fir density revealed relatively small changes in the fir density in RR and PE prior the mid 20th century, when compared with the second half of the same century. While old-growth inventories from 1950s indicated a gradual but significant decrease of fir density. The decrease peaked in KR, PE and RR during 1980s. Our data suggests that after this period the intensity of fir regression decreased again with the exception of ST. The synchronous trends of silver fir decline in old-growth forests can be closely linked to the records of $\mathrm{SO}_{2}$ emissions in Slovenia (ARSO, 2010). In the reference years 1980 and 1990, $\mathrm{SO}_{2}$ emissions in Slovenia amounted about 236,000 and $154,000 \mathrm{t} /$ year, respectively. For Slovenia emissions peak is estimated even earlier around 1978, when two largest coal power plants were finished. According to the information presented in Stern (2006) in the period from 1975 to 1993 east Europe was the world's largest emitter of sulphur. However, the $\mathrm{SO}_{2}$ emissions in Slovenia were not as high as in the northern Czech Republic, Germany, or south-western Poland ("Black Triangle"; Saltbones \& Dovland, 1986). On the other hand, the forests of Slovenia were also affected by $\mathrm{SO}_{2}$ emissions from Western and Northern Europe (Komlenovic, 1989).

In our research extended dbh classes (edbh) were used as proxies for assessing the social status of the trees. The results indicate variable fir decline rates among extended dbh classes. However, there was some evidence that overall fir decline rate was the highest in the edbh2 class $(30<\mathrm{dbh} \leq 55 \mathrm{~cm})$. When evaluating the impact of the extended dbh classes on silver fir decline, it should be noted that fir reduction in the edbh1 class was partly influenced by ungulate overbrowsing of fir regeneration, which started in the period after the WW II. 
Moreover, when comparing the fir decline among extended classes, also the influence of the windthrow of 1983 in PE has to be considered. At that time especially large diameter firs were affected (Nagel et al., 2006). Trees in edbh2 class were on average between 20 and $35 \mathrm{~m}$ high and thus had been just beginning to enter the upper canopy layer. Considering high overall tree density in old-growth forests, trees in medium layer might be stressed due to crown and root competition. Similar results were reported from early research on fir decline in Slovenian managed forests (Brinar, 1964), where lowest fir vitality was found in firs with dbh between 30 and $40 \mathrm{~cm}$. Our results are comparable with results of Becker (1989) who observed that dense stands and suppressed trees increased tree vulnerability to air pollution. On the other hand the hypothesis of large diameter trees being more susceptible to air pollution via wet deposition due to edge-effect (Filipiak \& Napierala-Filipiak, 2009) can not be confirmed. In general the interactions between emissions impact and tree social status are complex. Ferlin (1990) found in evenaged spruce forests with high $\mathrm{SO}_{2}$ emission loads that dominant trees were less damaged compared to co-dominant and suppressed trees. In the adjacent forest area with lower emission loads he found the opposite trend. Very likely, when studying the impact of emissions on trees of different social positions many different factors need to be taken into account: for example the distance to the main emission area, emissions mode (e.g. long or short range transport of emissions, wet or dry deposits) and the structure of the forest.

\section{Conclusion}

The literature outlines a number of possible causes for the acute fir decline during the second half of the last century. Very probably the reason was a complex interaction of many ecological factors. However, even more important than discussing possible influential factors is to highlight the predominant ones. Repeated inventories from old-growth forests in Slovenia and south-eastern Europe revealed a synchronous fir decline during the last fifty years, and a high association between $\mathrm{SO}_{2}$ emission loads and intensity of fir decline (Diaci et al., 2008). Therefore, the results support the opinion that the first and the fundamental factor of fir decline was the polluted atmosphere - especially $\mathrm{SO}_{2}$ emissions, while other factors including management, were of a lesser importance. Moreover, it may be likely that many other factors, like pathogens were more a consequence than a cause of the fir decline. However, fir density decrease in relatively remote old-growth forest areas, occasional fir vitality decline, as well as bark beetle calamities after extreme droughts (e.g. summer of 2003) confirm the impact of the climate change (warmer climate and incidence of summer draughts). Therefore, it seems that influences of air pollution and climate, which operate on different spatial scales, were related and they may have had a synergetic effect.

Our research indicated a greater sensitivity of the tree middle layer to air pollution, thus suggesting that the period of acute fir decline will be reflected in the mixed old-growth forest structure for centuries. Even more alarming is the fact that the fir regeneration overbrowsing by ungulates totally stopped fir recruitment. Thus, the fir density decrease will continue in spite of improved vitality. The results further suggest that for the future research of mixed old-growth forests more attention has to be devoted to the impact of polluted air, and indirect anthropogenic disturbances in general. Nevertheless, the reduced $\mathrm{SO}_{2}$ emissions on a Europe-wide level represent an important example of best practice for environmental conservation, which should more often exposed to the public and replicated in other areas of human induced environmental change. To maintain viable populations of 
silver fir, a coordinated action by all the domains of forest management, including silviculture, game management, hunting, harvesting and marketing, is a requisite.

\section{Acknowledgment}

This research was supported by the Slovenian Research Agency (Research Programme P40059: Forest, forestry and renewable forest resources) and the Ministry of Agriculture, Forestry, and Food (Project CRP V4-0540: Conservation ecology and management of fir in Slovenia). For help on the manuscript, I wish to thank Tomaz Adamic.

\section{References}

Anic, I.; Vukelic, J.; Mikac, S.; Baksic, D. \& Ugarkovic, D. (2009). Utjecaj globalnih klimatskih promjena na ekološku nišu obične jele (Abies alba Mill.) u Hrvatskoj. Sumarski list, Vol.133, No.3-4, pp. 135-144

ARSO, (2010). EIONET (Environmental Information and Observation Network), http://eionet-en.arso.gov.si/. ARSO Environmental Agency of the Republic of Slovenia

Becker, M.; Landmann, G. \& Levy, G. (1989). Silver fir decline in the Vosges mountains (France): Role of climate and silviculture. Water, Air, \& Soil Pollution, Vol.48, pp. 7786

Bert, G.D. (1993). Impact of Ecological Factors, Climatic Stresses, and Pollution on Growth and Health of Silver Fir (Abies-Alba Mill) in the Jura Mountains - an Ecological and Dendrochronological Study. Acta Oecologica, Vol.14, pp. 229-246

Blaschke, H. (1982). Schadbild und Ätiologie des Tannensterbens: III. Das Vorkommen einer Phytophthora-Fäule an Feinwurzeln der Weißtanne (Abies alba Mill.), European Journal of Forest Pathology, Vol.12, pp. 232-238

Boncina, A. (1999). Stand dynamics of the virgin forest Rajhenavski Rog (Slovenia) during the past century, In: Proceedings of the Invited Lecturers' Reports COST Action E4: Forest Reserves Research Network, Diaci, J. (Ed.), pp. 95-110, Plesko, Ljubljana

Brill, H.; Bock, E. \& Bauch, J. (1981). Über die Bedeutung von Mikroorganismen im Holz von Abies alba Mill. für das Tannensterben. Forstwiss. Cbl., Vol.100, pp. 195-206

Brinar, M. (1964). Zivljenjska kriza jelke na slovenskem ozemlju v zvezi s klimaticnimi fluktuacijami. Gozdarski vestnik, Vol.22, pp. 97-144

Cokl, M. (1992). Gozdarski prirocnik, Biotehniska fakulteta, Oddelek za gozdarstvo, Ljubljana.

Diaci, J.; Rozenbergar, D.; Mikac, S.; Anic, I.; Hartman, T. \& Boncina, A. (2008). Long-term changes in tree species composition in old-growth Dinaric beech-fir forest. Glasnik za sumske pokuse, Vol.42, pp. 13-27

Diaci, J.; Rozenbergar, D. \& Boncina, A. (2010). Stand dynamics of Dinaric old-growth forest in Slovenia: Are indirect human influences relevant? Plant Biosystems, Vol.144, pp. 194-201

Dobrowolska, D. (1998). Structure of silver fir (Abies alba Mill.) natural regeneration in the 'Jata' reserve in Poland. Forest Ecology and Management, Vol.110, pp. 237-247

Eckstein, D.; Aniol, R.W. \& Bauch, J. (1983). Dendroklimatologische Untersuchungen zum Tannensterben. European Journal of Forest Pathology, Vol.13, pp. 279-288

Elling, W. (1987). A procedure for the registration of the time course and degree of injury in conifer stands. European Journal of Forest Pathology, Vol.17, pp. 426-440 
Elling, W.; Dittmar, C.; Pfaffelmoser, K. \& Rötzer, T. (2009). Dendroecological assessment of the complex causes of decline and recovery of the growth of silver fir (Abies alba Mill.) in Southern Germany. Forest Ecology and Management, Vol.257, pp. 1175-1187

Ferlin, F. (1990). Vpliv onesnazevanja ozracja na rastno zmogljivost odraslih smrekovih sestojev, MSc Thesis, University of Ljubljana

Ficko, A. \& Boncina, A. (2006). Silver fir (Abies alba Mill.) distribution in Slovenian forests. Zbornik gozdarstva in lesarstva, Vol.79, pp. 19-35

Ficko, A.; Poljanec, A. \& Boncina, A. (2011). Do changes in spatial distribution, structure and abundance of silver fir (Abies alba Mill.) indicate its decline? Forest Ecology and Management, doi:10.1016/j.foreco.2010.12.014.

Filipiak, M. \& Napierala-Filipiak, A. (2009). Effect of canopy density on the defoliation of the European silver fir (Abies alba Mill.) due to heavy industrial pollution. Dendrobiology, Vol.62, pp. 17-22

Gill, R.M.A. (1992). A review of damage by mammals in north temperate forests: 3. Impact on trees and forests. Forestry, Vol.65, pp. 363-388

Hartman, T. (1987). Gozdni rezervati Slovenije - Pragozd Rajhenavski Rog. Univerza v Ljubljani, Biotehniska fakulteta, Ljubljana

Hockenjos, W. (2008). Tannenbäume - Eine Zukunft für Abies alba, DRW-Verlag Weinbrenner, Leinfelden-Echterdingen

Horvat, I.; Glavac, V. \& Ellenberg, H. (1974). Vegetation Sudosteuropas, G. Fischer, Stuttgart

Kenderes, K.; Mihok, B. \& Standovar, T. (2008). Thirty years of gap dynamics in a central European beech forest reserve. Forestry, Vol.81, pp. 111-123

Klopcic, M.; Jerina, K. \& Boncina, A. (2010). Long-term changes of structure and tree species composition in Dinaric uneven-aged forests: are red deer an important factor? European Journal of Forest Research, Vol.129, pp. 277-288

Komlenovic, N. (1989). Utjecaj $\mathrm{SO}_{2}$ i nekih drugih polutanata na sumsko drvece s posebnim osvrtom na SR Hrvatsku. Sumarski list, Vol.113, pp. 243-260

Korpel, S. (1995). Die Urwälder der Westkarpaten. Gustav Fischer Verlag, Stuttgart, Jena, New York

Kramer, W. (1992). Die Weißtanne (Abies alba Mill.) in Ost- und Südosteuropa. Gustav Fischer Verlag, Stuttgart, Jena, New York

Krause, G.; Arndt, U.; Brandt, C.J.; Bucher, J.; Kenk, G. \& Matzner, E. (1986). Forest decline in Europe: Development and possible causes. Water, Air and Soil Pollution, Vol.31, pp. 647-668

Larsen, B.J. (1986). Das Tannensterben: Eine neue Hypothese zur Klärung des Hintergrundes dieser Rätselhaften Komplexkrankheit der Weisstanne (A. alba Mill.). Forstw. Cbl., Vol.105, pp. 381-396

Leibundgut, H. (1974). Zum Problem des Tannensterbens. Schweiz. Z. Forstw., Vol.125, pp. $476-484$

Leibundgut, H. (1982). Europäische Urwälder der Bergstufe, Haupt, Bern

Levanic, T. (1997). Growth depression of silver fir (Abies alba Mill.) in the Dinaric phytogeographic region between 1960-1995. Zbornik gozdarstva in lesarstva, Vol.52, pp. 137-164

Mlinšek, D. (1964). Susenje jelke v Sloveniji - prvi izsledki. Gozdarski vestnik, Vol.22, pp. 145159 
Mlinsek, D. (1972). Ein Beitrag zur Entdeckung der Postojna Kontrollmethode in Slowenien. Forstw. Cbl., Vol.91, pp. 291-296

Motta, R. (1996). Impact of wild ungulates on forest regeneration and tree composition of mountain forests in the Western Italian Alps. Forest Ecology and Management, Vol.88, pp. 93-98

Nagel, T.A.; Svoboda, M. \& Diaci, J. (2006). Regeneration patterns after intermediate wind disturbance in an old-growth Fagus-Abies forest in southeastern Slovenia. Forest Ecology and Management, Vol.226, pp. 268-278

Peterken, G.F. (1996). Natural woodland: ecology and conservation in northern temperate regions, Cambridge University Press, Cambridge

Prelc, F., Veselič, Z., Jez, P. (1993). Rast jelke (Abies alba Mill.) se izboljšuje. Gozdarski vestnik, Vol.51, No.7-8, pp. 314-331

Prpic, B. (Ed.). (2001). Obicna jela (Abies alba Mill.) u Hrvatskoj. Akademija sumarskih znanosti, Zagreb

Puncer, I. (1980). Dinarski jelovo-bukovi gozdovi na Kocevskem. Razprave, Vol.22, No.6, pp. 161

Safar, J. (1951). Ugibanje i obnavljanje jele u prebornim sumama Gorskog Kotara. Sumarski list, Vol.75, pp. 299-303

Saltbones, J. \& Dovland, H. (1986). Emissons of sulphur dioxide in Europe in 1980 and 1983, EMEP MSC-W Report 1/86, Norwegian Meteorological Institute, Oslo

Schütt, P. (1978). Die gegenwärtige Epidemic des Tannensterbens. European Journal of Forest Pathology, Vol.7, pp. 187-190

Senn, J. \& Suter, W. (2003). Ungulate browsing on silver fir (Abies alba) in the Swiss Alps: beliefs in search of supporting data. Forest Ecology and Managemet, Vol.181, pp. 151164

Stern, D.I. (2006). Reversal of the trend in global anthropogenic sulphur emissions, Global Environmental Change, Vol.16, pp. 207-220

Thomas, A.-L.; Gegout, J.-C.; Landmann, G.; Dambrine, E. \& King, D. (2002). Relation between ecological conditions and fir decline in a sandstone region of the Vosges mountains (northeastern France). Annals of Forest Science, Vol. 59, pp. 265-273

Ulrich, B. (1981). Eine ökosystemare Hypothese über die Ursachen des Tannensterbens (Abies alba Mill.). Forstwiss. Cbl., Vol.100, pp. 228-236

Vrska, T.; Adam, D.; Hort, L.; Kolár, T. \& Janík, D. (2009). European beech (Fagus sylvatica L.) and silver fir (Abies alba Mill.) rotation in the Carpathians: A developmental cycle or a linear trend induced by man? Forest Ecology and Management, Vol.258, pp. 347-356

Wentzel, K.F. (1980). Weissitanne $=$ immissionsempfindlichste einheimische Baumart. Allgemeine Forstzeitschrift, Vol. 35, pp. 373-374

Wick, L. \& Möhl, A. (2006). The mid-Holocene extinction of silver fir (Abies alba) in the Southern Alps: a consequence of forest fires? Palaeobotanical records and forest simulations. Vegetation History and Archaeobotany, Vol.15, pp. 435-444 


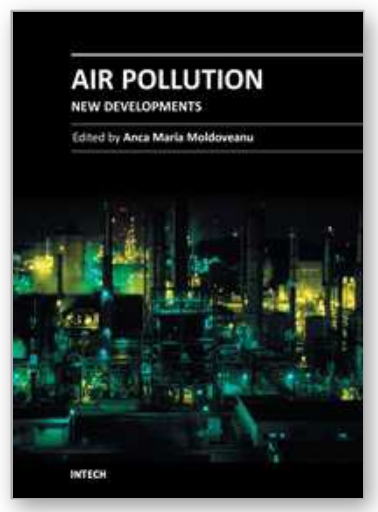

\author{
Air Pollution - New Developments \\ Edited by Prof. Anca Moldoveanu
}

ISBN 978-953-307-527-3

Hard cover, 324 pages

Publisher InTech

Published online 06, September, 2011

Published in print edition September, 2011

Today, an important issue is environmental pollution, especially air pollution. Due to pollutants present in air, human health as well as animal health and vegetation may suffer. The book can be divided in two parts. The first half presents how the environmental modifications induced by air pollution can have an impact on human health by inducing modifications in different organs and systems and leading to human pathology. This part also presents how environmental modifications induced by air pollution can influence human health during pregnancy. The second half of the book presents the influence of environmental pollution on animal health and vegetation and how this impact can be assessed (the use of the micronucleus tests on TRADESCANTIA to evaluate the genotoxic effects of air pollution, the use of transplanted lichen PSEUDEVERNIA FURFURACEA for biomonitoring the presence of heavy metals, the monitoring of epiphytic lichen biodiversity to detect environmental quality and air pollution, etc). The book is recommended to professionals interested in health and environmental issues.

\title{
How to reference
}

In order to correctly reference this scholarly work, feel free to copy and paste the following:

Jurij Diaci (2011). Silver Fir Decline in Mixed Old-Growth Forests in Slovenia: an Interaction of Air Pollution, Changing Forest Matrix and Climate, Air Pollution - New Developments, Prof. Anca Moldoveanu (Ed.), ISBN: 978-953-307-527-3, InTech, Available from: http://www.intechopen.com/books/air-pollution-newdevelopments/silver-fir-decline-in-mixed-old-growth-forests-in-slovenia-an-interaction-of-air-pollutionchanging-

\section{INTECH}

open science | open minds

\section{InTech Europe}

University Campus STeP Ri

Slavka Krautzeka 83/A

51000 Rijeka, Croatia

Phone: +385 (51) 770447

Fax: +385 (51) 686166

www.intechopen.com

\section{InTech China}

Unit 405, Office Block, Hotel Equatorial Shanghai

No.65, Yan An Road (West), Shanghai, 200040, China 中国上海市延安西路65号上海国际贵都大饭店办公楼 405 单元

Phone: +86-21-62489820

Fax: $+86-21-62489821$ 
(C) 2011 The Author(s). Licensee IntechOpen. This chapter is distributed under the terms of the Creative Commons Attribution-NonCommercialShareAlike-3.0 License, which permits use, distribution and reproduction for non-commercial purposes, provided the original is properly cited and derivative works building on this content are distributed under the same license. 